the Tonga and Viti clusters, with Rotuma, Uvea, and Fakaafo. He maintains that there was a later migration of the same race, the course of which into Polynesia cannot now be traced. These second comers he calls the Tongafiti, and regards them as having been so long separated from the proto-Samoan that their language had independently and divergently developed. But during the dominance of the Tongafiti in Nuclear Polynesia their speech had become mixed to some extent with the proto-Samoan.

After the expulsion of the Tongafiti from Samoa about the eleventh century of our era, they took refuge in the islands eastward, the Cook and Austral Islands, which became the centre of the migrations which ultimately reached Hawaii and New Zealand. This central region is not dealt with in Mr. Churchill's present work, and he defines the region discussed as "south-east Polynesia," comprising the Paumotu group with Manqareva, the Marquesan and Tahitian groups, and Rapanui or Easter Island.

Mr. Churchill's material for the examination of the languages consists mainly of the vocabularies collected by the French missionaries in Rapanui, the Marquesas, and Tahiti, with Tregear's vocabularies of Paumotu and Mangareva, also derived from French sources. All these lack, as Mr. Churchill notes, the fullness and detail of the Samoan, Tongan, and Maori dictionaries of Pratt, Baker, and Williams, for they start with an original list in French, for which their compilers have sought to ascertain the Polynesian equivalents.

Mr. Churchill's method in the present work is similar to that followed in the "Polynesian Wanderings." After a valuable discussion of the Polynesian alphabet, and of metathesis in Polynesian words, he deals with the sources and variety of Rapanui speech, deducing from its treatment of modern loan-words (European) its principles of deviation from the Polynesian standard. Then, by an examination of the Rapanui vocabulary, he proceeds to distinguish the words which occur (x) in both proto-Samoan and Tongafiti; (2) in proto-Samoan alone; and (3) in Tongafiti only. The first are called general Polynesian. In a table of 957 Rapanui words he refers 436 to general Polynesian, I Io to proto-Samoan (i.e. with cognates in Samoan), and rro to Tongafiti (i.e. with cognates in Maori). But 292 words are restricted to south Polynesia alone, that is, have cognates only in Paumotu, Mangareva, the Marquesas, and Tahiti. He states that "the proto-Samoan element represents an older and more primitive type than is shown in the modern languages of Nuclear Polynesia," pointing to the migration from Samoa as having taken place whilst two aspirates were in use, and before the formative elements had been acquired which have enobled the language in Nuclear Polynesia to maintain the final consonant of a closed stem, as it Mr. Churchill's proto-Samoan stem ikof, which became $i$ 'ofi in Samoan and iko in Rapanui.

Paumotu is regarded as the "sfcond station if the Tongafiti migration after its expulsion from Samoa, and its centre of distribution to the seats of the present great settlements of this swarm." Mangareva is also dealt with as a centre of distribution, and the Marquesas as affording indications of their being in the fairway of the migration to Hawaii. All these are numerically dealt with, and their words classified as general Polynesian, proto-Samoan, and Tongafiti. A very important result appears in the statement that in the Paumotu vocabulary, whilst 52 per cent. of its words are cognate with the other Polynesian languages, 48 per cent. are found peculiar to Paumotu. Mr. Churchill regards these words as true Polynesian which have gone out of use, as Polynesian words are prone to do, or have been invented to express a new environment, and quotes Dr. Friederici on word-tabu and the theoretical formation of new words. Here two important facts seem to have been lost sight of. In other languages the words used as substitutes for tabuwords are not usually new inventions, else they would not be understood by the hearers, but are words really belonging to the languages, though not in general use. Similarly, unless a foreign word is introduced, a new object or action is named by a word already known. In the opinion of the present writer, the fact that the peculiar Paumotu words are totally unlike any others in the island region (except a few in the allied Tahitian) appears to show that they are not Polynesian at all, but rather a remnant of some pre-Polynesian speech.?

Mr. Churchill finds in the four languages discussed a wide speech-group of broad diffusion and of considerable complexity. He subdivides this into: (I) a Polynesian speech which has passed from the use and memory of other Polynesians; (2) a later proto-Samoan colony taking refuge from Tongafiti tyranny; (3) a Tongafiti settlement; (4) a migration of associated proto-Samoan and Tongafiti from the west which was caught in the Paumotu chain, only a few stragglers reaching the other groups; (5) from the Paumotus, part of a subsequent migration reached Rapanui, the last home of the Polynesians.

Apart from its theory, with all the interesting issues involved, Mr. Churchill's book has the very practical advantage of presenting in a convenient form Rapanui, Paumotu, Mangarevan, Tahitian, and Marquesan vocabularies, with an extremely useful finding-list in English and Rapanui. The student, whether in accord with Mr. Churchill's theory or not, will find it of much value as a record of the languages.

Sidney H. Ray.

\section{THE SOUTH AFRICAN NATIONAL BOTANIC GARDEN.}

THE work of the last session of the Union Parliament included the establishment of a National Botanic Garden at the Cape. This was the natural outcome of the cordial reception given in the House of Assembly to the resolution moved by Si- Lionel Phillips on May 6.

2 C. Reports of Cambridge Anthropological Expedition to Torres Straits, vol. iii., p. 5 ig et seq.

NO. 2285 , VOL. 9I] 
Kirstenbosch, the site selected, is peculiarly favourable for the purpose, and affords scope for the development of a singularly beautiful South African garden. It is a farm on the Rhodes estates, to the south of Groote Schur, on the eastern slopes of Table Mountain. It contains the ruins of at least three old homesteads, and was probably occupied very early in the history of the settlement of this portion of the Cape Peninsula. The country seat of Van Riebeek, the first Dutch Governor (1652-1662), adjoins Kirstenbosch on its eastern boundary, and, according to tradition, Van Riebeek obtained from the latter a large supply of native woods for building purposes.

The survey of the Kirstenbosch estate is not vet completed; its area is probably about 400 acres. Of this, the eastern half consists of flat or slightiy undulating land, about $200 \mathrm{ft}$. above sea-level. Above this the western half rises. to about I0oo or I500 ft. The latter includes the lower ends of three richly wooded gorges, in which the native vegetation during recent years has been little interfered with except by occasional fires. The lower-lying parts have been heavily planted with pines ( $P$. pinaster and $P$. pinea), oaks, and poplars. Here the native bush has been mostly exterminated. The poplars have completely taken possesion of considerable areas. The oaks, most of which were pollarded many years ago, have been altogether neglected, and now, with few exceptions, are in an advanced state of decay.

The underlying rock, except perhaps in the most elevated parts of the estate, is granite. The slopes, however, are for the most part strewn with blocks of Table Mountain sandstone, fallen from above. Along one edge of the area there is believed to be an outcrop of Malmesbury slates. Many acres are overlain by a rich denosit of humus derived mainly from the oaks and the poplars. The water supply is exceptionally good. Two of the streams from the adjacent gorges, traversing the whole breadth of the estate, are permanent, and a spring, issuing about $200 \mathrm{ft}$. above the eastern boundary, is perennial. It will therefore be a matter of no great difficulty to irrigate as much of the cultivated land as may be necessary. In the cultivation of South African vegetation the importance of aspect is very considerable. Kirstenbosch offers a choice which is unlimited, save towards the west (where it is shut in by the lower slopes of Table Mountain), and also, of course, there is no direct exposure to the sea. Another factor which calls for careful consideration is that of wind. The well-known Cape South-Easter, which is of frequent occurrence during the season of most active growth and of flowering, has a most injurious effect upon very many species. Owing to the curvature of the Table Mountain range between Mowbray and Muizenberg, and the situation of Kirstenbosch in the curve, the south-east wind rarely reaches it.

Kirstenbosch, therefore, possesses a combination of natural features which make it eminently NO. 2285 , VOL. 9I] suitable for the cultivation and study of a very large proportion of the varied floras of South Africa. It already bears several hundreds of species more or less representative of the Cape region itself. Experience already obtained of the cultivation in the Cape Peninsula of dry-climate species from Namaqualand and the central plateau, and of sub-tropical forms from the southeastern coast belt, affords no room for doubt that many of these also will find a suitable home side by side with the flora of Table Mountain and the adjacent Cape Flats.

The control of the garden is vested in a board of five trustees, to which the following have been nominated by the Grovernment :--Lord de Villiers, Sir David Graaff, Sir Lionel Phillips. Two further nominations are yet to be made, one by the Corporation of Cape Town, and another by the Botanical Society of South Africa, constituted for the purpose of giving general and financial support to the project.

The trustees have made the following appointments :--Hon. director, Prof. H. H. W. Pearson; secretary, Miss H. J. Davison. Plans for a director's residence and a laboratory have been approved. A gardening staff will be apoointed immediately.

\section{WIRELESS TIME SIGNALS.}

IN the Annuaire for $\mathrm{rgr}_{3}$ of the Paris Bureau des Longitudes will be found a full account by Commandant Ferrié of the development of wireless time-signalling.

For a long period in the past local time was the only requirement of this kind, until the discovery of America rendered the determination of longitude at sea a matter of great practical importance, thus making the knowledge of the time on a fixed meridian as necessary as that of local time. The growth of railway enterprise in the nineteenth century made the adoption of standard time over large districts an obvious convenience, with the result that different countries adopted their own standard time, and Paris time, for instance, was made legal time throughout France in March, I89I. The subsequent gradual adoption of Greenwich time, or time differing from Greenwich by an exact number of hours or halfhours, has continued until the present time, France, only so recently as March, I9I r, substituting Greenwich time for Paris time throughout France and Algeria.

The accurate determination of local time (or Greenwich time altered by a constant) comes into the domain of practical astronomy, and is responsible for a considerable amount of routine work, especially at Government observatories. The difference of longitude between two stations, including, for instance, the "constant" mentioned above, has provided a problem the solution of which has steadily progressed towards accuracy since the invention of the electric telegraph; but for any place not in telegraphic communication with a fixed observatory the greatest stride in 